\title{
NOTE FROM THE EDITORS
}

The grand department store served as one of the most impressive spectacles of the Gilded Age and Progressive Era. With this issue we seek to emulate the success of Wanamaker's and Filene's by opening up yet another department in our multifaceted editorial enterprise-in this case, "Public Engagement."

Richard L. McCormick-the former president of Rutgers and the University of Washington-inaugurates the Public Engagement section with an essay on the history of American corruption. In the form of an extended review of former New York gubernatorial candidate and law professor Zephyr Teachout's book on the subject, McCormick seeks to discern what the past might tell us about the nation's current politics in the age of Citizens United and McCutcheon v. Federal Election Commission. Early in his career one of the leading historians of Progressive Era politics, McCormick essentially here resumes his scholarly career, the center of which will be his own book-length project on the history of corruption. He recognizes the particular significance of the Progressive Era—but not just for understanding the past. McCormick also argues that revisiting the early twentieth-century campaign against the rule of money over politics may provide us with a glimmer of democratic hope today.

Little did we know that when we actively sought to open up the Journal of the Gilded Age and Progressive Era to energetic engagement with the present that we would soon have a bevy of contributors discussing the so-called Islamic State. Yet contemporary civic life is now extreme enough in certain corners that one potential Republican candidate for president, Ben Carson, has expressed his concern that the politics of the history classroom have become so anti-American under the new Advanced Placement United States History exam that this "APUSH" course might become an effective recruiting ground for ISIS.

In our second "Teaching Forum," a diverse set of scholars and teachers explores the politics and pedagogy of the new APUSH framework, fortunately finding that its goals lie less in the realm of beheading and more in filling the heads of the nation's students with advanced historical thinking skills. Lawrence Charap, who led the redesign of the exam and curricular framework, begins the forum with an essay that explains how the rethinking occurred and what the new exam and framework actually look like. Jeremy Stern, a historian and conservative educational policy commentator, then offers his assessment, and sometimes critique, of the way that the new design handles various issues both inside and outside the Gilded Age and Progressive Era. Stern does express concern about some of the liberal slant in the implicit politics of the new course design. Yet on the whole he offers a sharp rebuke to Carson (and the Republican National Committee, which has also repudiated the reckless revisionism of the new exam) when he persuasively demonstrates how much of the course is truly devoted to trans-ideological historical thinking skills.

Three practicing APUSH high school teachers, Brenda Santos, Saul Straussman, and Mary Lopez, then talk about what the new course is like on the ground, in actual classrooms. Their general finding is that the course redesign offers an exciting (although 
challenging) opportunity to focus in-depth on matters ranging from local to labor history, providing students a welcome respite from the previous exam's relentless attention to facts and thus offering APUSHers an opportunity to engage in authentic historical inquiry, investigation, and interpretation. The delightfully contrarian Jonathan Zimmerman then enters the fray by turning the whole issue on its head. If the purpose of the Advanced Placement course is to mimic a college-level course, do we really want that when so many college history survey courses are taught in such a retrograde fashion, with no concern for top-level pedagogy? College professors, beware, you have a horse in this race whether you want to admit it or not! In a concluding synthesis and assessment, Lendol Calder gently disagrees with Zimmerman, arguing that the best practices of $\mathrm{K}-12$ social studies classrooms - as represented in the AP redesign-are finally bubbling upwards to colleges and universities (note the direction of transmission). Yet Calder contends that we need to recognize the legitimacy of some of the criticisms of APUSH, especially because they ultimately reveal how the messy, raucous, democratic contention at the center of the debate delightfully mirrors the kind of vigorous interpretive conflicts that we should also hope to cultivate in our history classrooms.

One of the goals of the new AP framework is to encourage high school students to reflect on-really, to *do*-historiography (something that, in general, they are actually quite capable of). Toward the end of this journal's mission to revitalize such reflections, we include the second contribution to our new "Historiographical Interventions" section. Louise Newman contributes an outstanding essay that places Aileen Kraditor's The Ideas of the Woman Suffrage Movement (1965) at the headwater of several streams of significant scholarly writings over the last fifty years. Newman reveals how some feminist historians, in the first decade after its publication, believed Ideas to be about too traditional a subject, covered in too traditional a manner. Yet Newman shows how Kraditor's classic first book came to serve as the foundation for an outpouring of works that sought to reveal the complex interplay of antidemocratic and democratic impulses within the suffrage movement - particularly on matters of race. Kraditor thus clearly asked the right, enduring, questions - even if some of her answers (such as the distinction between "justice" and "expediency" in arguments for suffrage) do not necessarily hold up well.

This issue also contains its standard core of research-based essays and book reviews (along with a movie review from Timothy Gilfoyle of The Immigrant, a dark meditation on early twentieth-century sexual exploitation starring Marion Cotillard, Joaquin Phoenix, and Jeremy Renner). Our first two articles examine different aspects of the imperial history of the United States, and they are united in highlighting divisions and fissures in the larger system of empire. Paul Kramer explores Chinese exclusion on a largerthan-usual canvass in "Imperial Openings: Civilization, Exemption, and the Geopolitics of Mobility in the History of Chinese Exclusion, 1868-1910." Kramer points to the centrality of the tens of thousands of Chinese permitted to travel and live in the United States during this period because of the benefit they provided in perpetuating American imperial economic interests in East Asia. American exporters, missionaries, and diplomats insisted that their Chinese counterparts be afforded privileges denied to Chinese laborers. The entanglements of empire thus actually weakened exclusion, ultimately giving lie to the racist dream of complete separation-while simultaneously solidifying the power of more complex imperial racial structures. 
The 1898 acquisition of the Philippines and Puerto Rico, plus the effective control over Cuba, formally made the United States a formal overseas as well as an informal economic and continental empire. American citizens were far from united about the wisdom of becoming such an imperial power. In "A Church Divided: Roman Catholicism, Americanization, and the Spanish-American War," Benjamin Wetzel examines the neglected role of religion in debates over the Spanish-American War. Wetzel interprets the embrace of providentialist interpretations of the war by some Catholics as evidence of the Americanization of the once-marginal church. On the other hand, the opposition of other Catholics reflected the continued skepticism they held about not only the war, but the virtues of the United States itself. Empire was no mere matter of military might or foreign policy.

Jeremy Young rounds out our article section with an exploration of the grassroots followers of the arch-Protestant Billy Sunday. Carefully and imaginatively using letters from Sunday's followers as his primary archive, Young seeks not only to document what the evangelical masses said about their experience of conversion, but to credit and respect the deep emotional response many Americans had to the uber-masculine, baseball-playing minister. Sunday's followers come off as both thoughtful and feeling, in a way that the secular academy often fails to take as seriously as it might. And Young's essay has a larger purpose: not just to call attention to the masses of supporters that made, and make, any social movement truly important, but to help us see the need more generally for a robust history of emotions in the Gilded Age and Progressive Era.

We hope that you enjoy browsing through our intellectual emporium! 